\title{
Initial Genetic Evidence of Population Structure of Greenland Halibut (Reinhardtius hippoglossoides) in the Northwest Atlantic
}

\author{
Cristina Pomilla \\ Sackler Institute for Comparative Genomics, American Museum of Natural History, \\ Central Park West at $79^{\text {th }}$ Street, New York, NY 10024, USA \\ Email: cpomilla@amnh.org, cristina.pomilla@nyu.edu
}

Margaret A. Treble, Lianne D. Postma, Melissa M. Lindsay and James D. Reist Fisheries and Oceans Canada, Central and Arctic Region, 501 University Crescent, Winnipeg, MB R3T 2N, Canada.

Pomilla, C., M. A. Treble, L. D. Postma, M. M. Lindsay, and J. D. Reist. 2008. Initial genetic evidence of population structure of Greenland Halibut (Reinhardtius hippoglossoides) in the Northwest Atlantic. J. Northw. Atl. Fish. Sci., 40: 1-15. doi:10.2960/J.v40.m637

\begin{abstract}
Greenland halibut (Reinhardtius hippoglossoides) supports one of the major groundfish fisheries of the Northwest Atlantic and its biological stock structure is an important management concern. Using nuclear DNA microsatellite markers and a combination of summary statistics and Bayesian inference, we identified two distinct stocks, both represented within the Baffin Island-West Greenland complex and in the Gulf of St. Lawrence. While a North-South pattern of genetic structure was not supported, our data suggest East-West differentiation within Baffin Bay and Davis Strait. Genetic distances between samples were not correlated with geographic distances, and some degree of intermingling of the two stocks within the same assemblages was detected. Our preliminary results warrant further investigation of the observed patterns with the support of an intensive sampling scheme.
\end{abstract}

Keywords: Flatfish, genetics, Greenland halibut, microsatellites, Reinhardtius hippoglossoides, stock structure.

\section{Introduction}

The extent of the subdivision of a species into populations and the gene flow among these are of fundamental importance to the conservation and management of marine fisheries. Weak structure is often expected in marine fish populations due to the lack of geographic barriers (Ward, 2000). For benthopelagic flatfish species, high levels of dispersal due to the prolonged larval phase may result in panmixia at oceanic, regional and subregional scales (Bailey, 1997; Hoarau et al., 2002). Nevertheless, oceanic currents (Shaw et al., 2004), or salinity and temperature gradients (Nielsen et al., 2003) may constitute a barrier to gene flow. In the past few years an increasing number of studies have inferred population subdivision in marine fishes even on limited geographic scales (Knutsen et al., 2003; Taylor and Hellberg, 2003). Similarly, evidence of population differentiation has also accumulated for flatfishes (Bailey, 1997; Hoarau et al., 2002).
Greenland halibut (Reinhardtius hippoglossoides) is a flatfish species widely distributed within the North Pacific and the North Atlantic oceans. In the Northwest Atlantic this species is found as far north as Smith Sound $\left(78^{\circ} \mathrm{N}\right)$ to as far south as the Scotian $\operatorname{Shelf}\left(44^{\circ} \mathrm{N}\right)$ (Bowering and Brodie, 1995). The highest densities occur above $500 \mathrm{~m}$ depths along the edge of the continental slope, as well as in the fjords of West Greenland and the deepwater bays of eastern Newfoundland and the Gulf of St. Lawrence (Bowering and Brodie, 1995).

Since the moratorium on Atlantic cod (Gadus morhua) and the decline of most other flatfish species (FRCC, MS 1994; NAFO, MS 1994; Devine et al., 2006), Greenland halibut has attracted significant attention and has rapidly gained great importance for intensive fisheries. Its acquired status as a major groundfish fishery, combined with modern advances in fishing technology, resulted in a doubling of annual catches in the early 1990s (Bowering and Brodie, 1995). However, subsequent de- 
cline of populations and catches (Bowering and Brodie, 1995) has raised management concerns, exacerbated in view of the potential impact of climate change (Roessig et al., 2004; ACIA, MS 2005).

Greenland halibut in the Northwest Atlantic are managed according to a system of statistical subareas and divisions established by the Northwest Atlantic Fisheries Organization (NAFO). According to this system the Northwest Atlantic is managed as four separate units: (1) Baffin Island-West Greenland (NAFO Subarea 0, Division 1A-offshore, and Divisions 1C-F); (2) West Greenland Inshore (NAFO Division 1A-inshore); (3) Labrador-eastern Newfoundland (NAFO Subarea 2 and Divisions 3KLMNO); and (4) Gulf of St. Lawrence (NAFO Divisions 4RST) (Bowering and Chumakov, 1989; Bowering and Brodie, 1995).

Most of the spawning for the Northwest Atlantic is believed to occur in an extended area from Davis Strait (Subareas 0 and $1, c a .67^{\circ} \mathrm{N}$ ) to south of Flemish Pass off Newfoundland (Jensen, 1935; Smidt, 1969; Templeman, 1973; Junquera and Zamarro, 1994). A smaller self-sustaining spawning stock is located in the Gulf of St. Lawrence (Templeman, 1970; Bowering, 1980), although recruitment of fish into the Gulf of St. Lawrence from the Davis Strait and the Labrador stock has also been suggested (Bowering, 1982). Dispersal in Greenland halibut may happen through active migration of adults or through passive drift of eggs and larvae with water masses. The larvae and early juveniles remain pelagic for the first few months of life, during which time they may be carried even long distances away from their spawning site most likely by surface currents (Jensen, 1935; Smidt, 1969; Templeman, 1973). Tagging studies have also shown that as Greenland halibut approach maturity, they may migrate to reach spawning sites (Bowering, 1984; Boje, 2002).

Several approaches have been used to investigate stock boundaries for the Northwest Atlantic Greenland halibut, including analyses of meristic characters (Templeman, 1970; Riget et al., 1992), parasite prevalence (Khan et al., 1992; Arthur and Albert, 1993; Boje et al., 1997), tagging data (Smidt, 1969; Boje, 2002), allozymes (Fairbairn, 1981; Riget et al., 1992) and mitochondrial DNA (mtDNA) (Vis et al., 1997). All these studies suggest that the Northwest Atlantic Greenland halibut form a single stock with the exception of the fish of the Gulf of St. Lawrence, which form a self-sustaining stock, and the fish of the West Greenland fjords, which differentiate from the Davis Strait stock based on the number of vertebrae.

Genetic structure may often be subtle (Wirth and Bernatchez, 2001), and as such difficult to detect. Nuclear DNA hypervariable markers, such as microsatellites, are powerful tools for the discrimination of genetic stocks (Ward, 2000), and often more effective than mtDNA (Shaw et al., 1999). Microsatellites have been successfully used to investigate patterns of genetic structure for Greenland halibut within the Northeast Atlantic, revealing also differences between the Northeast and Northwest Atlantic stocks (Knutsen et al., 2007).

Here we present an initial investigation of the population structure of Greenland halibut within the Northwest Atlantic through analyses of microsatellite genotypes. Our objectives are: (1) to evaluate whether subtle population structure has previously been undetected due to sampling scheme or lack of power of the marker of choice; (2) to assess whether an isolation-by-distance model can explain any observed genetic structure; and (3) to identify the number of genetically distinguishable populations.

\section{Materials and Methods}

\section{Sample collection}

The study area spans two of the current NAFO recognized stocks; the Baffin Island-West Greenland stock (Subarea 0, Division 1A-offshore, and Divisions 1C-F), and the Gulf of St. Lawrence stock (Divisions 4RST).

Samples of skeletal muscle were collected between 1993 and 2001 during trawl surveys (Treble, MS 2002) at 12 sampling sites (Fig. 1, Table 1) and stored in saltsaturated 20\% DMSO. Three of these sites were sampled in multiple years. With the exception of the winter fishery in the Cumberland Sound (CSw), where samples were collected in February/March and could include spawning fish, all other localities were sampled in summer and autumn. Larval fish were collected at one site near the West Greenland fjords (1C). In the Gulf of St Lawrence, samples were collected on two different occasions in 1994. The first sampling event (SL1) took place within Divisions 4RST between August and early September and samples were from throughout the survey area (although most came from 4S) (Fig. 1). The second set of samples (SL2) was collected on 15 September at a single location within Division 4T. 


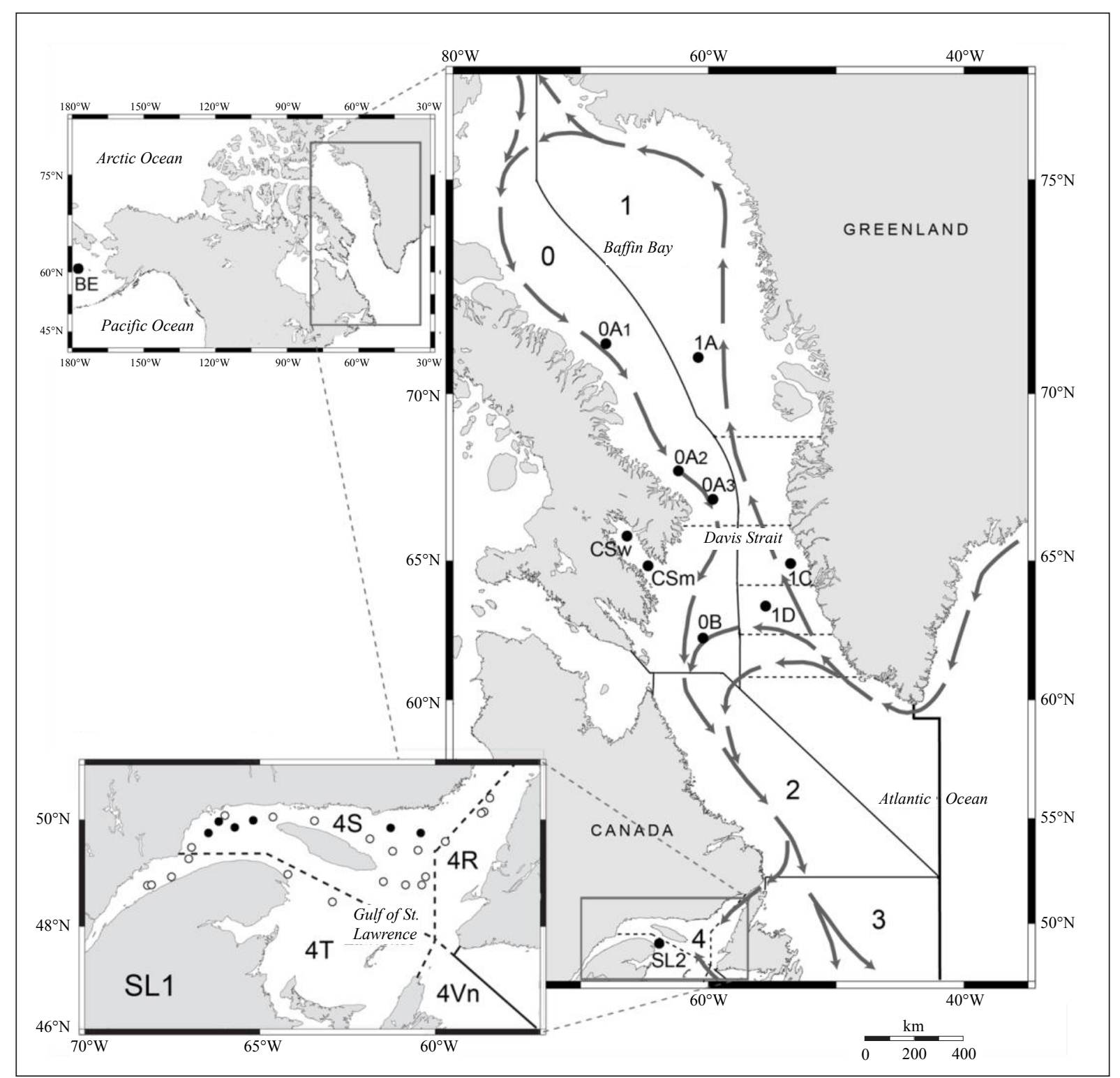

Fig. 1. Map showing sampling locations (refer to Table 1 for sample abbreviations) and NAFO Regulatory Subareas and Divisions. Arrows indicate the main deep-water currents. The inset at the bottom indicates the distribution of the samples collected in the Gulf of St. Lawrence between 18 August and 7 September 1994 (SL1). Full circles refer to multiple samples; open circles indicate collection of a single fish.

An additional sampling site offshore of the coast of Alaska in the Bering Sea (BE), North Pacific Ocean, was included in the study. The inclusion of a distant area in the analysis allowed us to verify the resolving power of the markers used.

\section{DNA extraction and microsatellite genotyping}

Total genomic DNA was extracted from the muscle tissue using DNAeasy tissue kit (Qiagen). Four di- nucleotide microsatellite loci (Hhi3, Hhi55, Hhi57 and HhiA44) previously developed for the Atlantic halibut (Hippoglossus hippoglossus) were selected from the literature (McGovan and Reith, 1999; Coughlan et al., 2000). An additional marker (Po91) previously characterized in the Japanese flounder (Paralichtys olivaceus) was added (Sekino and Hara, 2000). Polymerase chain reaction (PCR) conditions are available upon request. Pooled PCR products were analyzed on an ABI 377 or 
TABLE 1. Greenland halibut collection statistics for a total of 497 individuals.

\begin{tabular}{|c|c|c|c|c|c|}
\hline \multirow[b]{2}{*}{ Collection location and date } & \multirow[b]{2}{*}{$n$} & \multicolumn{2}{|c|}{ Mean location } & \multicolumn{2}{|c|}{ Length $(\mathrm{cm})$} \\
\hline & & $\begin{array}{c}\text { Latitude } \\
\left({ }^{\circ} \mathrm{N}\right)\end{array}$ & $\begin{array}{c}\text { Longitude } \\
\left({ }^{\circ} \mathrm{W}\right)\end{array}$ & Range & Mean \\
\hline \multicolumn{6}{|l|}{ NAFO Subarea 0} \\
\hline \multicolumn{6}{|l|}{ Division $0 A$} \\
\hline Baffin Bay offshore (0A1), 1999 & 14 & 71.29 & 67.99 & $45-64$ & 54.2 \\
\hline Baffin Bay offshore (0A2), 1993 & 25 & 67.75 & 62.32 & $36-61$ & 46.4 \\
\hline Baffin Bay offshore (0A2), 1999 & 12 & 67.89 & 62.17 & $36-63$ & 47.5 \\
\hline Baffin Bay offshore (0A2), 2001 & 20 & 67.89 & 62.50 & $44-53$ & 48.6 \\
\hline Baffin Bay offshore (0A3), 1999 & 19 & 66.97 & 59.65 & $25-63$ & 42.0 \\
\hline \multicolumn{6}{|l|}{ Division $O B$} \\
\hline Davis Strait offshore (0B), 1993 & 39 & 62.55 & 60.77 & $25-41$ & 34.8 \\
\hline Davis Strait offshore (0B), 2001 & 18 & 62.11 & 60.06 & $38-71$ & 48.9 \\
\hline Cumberland Sound winter fishery (CSw), 1993 & 48 & 65.75 & 66.50 & $47-81$ & 62.3 \\
\hline Cumberland Sound winter fishery (CSw), 1994 & 48 & 65.82 & 66.37 & $57-85$ & 66.0 \\
\hline Cumberland Sound mouth (CSm), 1994 & 50 & 64.84 & 64.72 & $31-70$ & 47.4 \\
\hline \multicolumn{6}{|l|}{ NAFO Subarea 1} \\
\hline \multicolumn{6}{|l|}{ Division $1 A$} \\
\hline Baffin Bay offshore (1A), 2001 & 20 & 70.94 & 60.79 & $52-81$ & 64.7 \\
\hline \multicolumn{6}{|l|}{ Division $1 C$} \\
\hline West Greenland inshore (1C), 1999 & 47 & 64.92 & 53.58 & $1.2-3.27$ & 2.56 \\
\hline \multicolumn{6}{|l|}{ Division $1 D$} \\
\hline Davis Strait offshore (1D), 2001 & 20 & 63.47 & 55.54 & $45-105$ & 65.2 \\
\hline \multicolumn{6}{|l|}{ NAFO Subarea 4} \\
\hline \multicolumn{6}{|l|}{ Divisions $4 R S T$} \\
\hline Gulf of St Lawrence (SL1), 1994 & 43 & \multicolumn{2}{|c|}{ see Fig. 1} & $36-66$ & 44.5 \\
\hline \multicolumn{6}{|l|}{ Divisions $4 T$} \\
\hline Gulf of St Lawrence (SL2), 1994 & 25 & 49.02 & 64.08 & $30-48$ & 38.7 \\
\hline \multicolumn{6}{|l|}{ North Pacific Ocean } \\
\hline Bering Sea (BE), 1994 & 49 & 60.67 & 177.74 & $31-70$ & 44.9 \\
\hline
\end{tabular}

3100 DNA analyzer (Applied Biosystems), and alleles were sized with the software GENESCAN v.3.1 and GENOTYPER v.2.1 (Applied Biosystems).

Additionally, genotypes constructed from nine microsatellite loci (Hhi1, Hhi3, Hhi52, Hhi53, Hhi55, Hhi59 HhiA44, HhiC17, HhiI29, McGovan and Reith, 1999; Coughlan et al., 2000) by Norwegian colleagues were also available for a smaller set of samples (see Knutsen et al. (2007) for methodology).

\section{Data analyses}

Number of alleles per locus $\left(N_{\mathrm{A}}\right)$, allelic richness $(A)$, observed heterozygosity $\left(H_{\mathrm{O}}\right)$, and the heterozygos- ity expected $\left(H_{\mathrm{E}}\right)$ under Hardy-Weinberg equilibrium assumptions (Nei, 1987) were calculated in FSTAT v.2.9.3 (Goudet, 1995). Hardy-Weinberg equilibrium (HWE) and linkage disequilibrium (LD) were evaluated with a probability test (Guo and Thompson, 1992) implemented in GENEPOP v.3.4 (Raymond and Rousset, 1995). $F_{\text {IS }}$ values were estimated according to Weir and Cockerham (1984) and significance was tested using permutations with the software GENETIX v.4.05 (Belkhir et al., 2004). Significance levels $(p=0.05)$ for departure from HWE, LD and $F_{\text {IS }}$ were adjusted for simultaneous comparisons with the sequential Bonferroni correction (Rice, 1989). MICROCHECKER v.2.2.3 was used to test for the presence of null alleles (van Oosterhout et al., 2004). 
Temporal homogeneity in allele frequencies was tested in GENEPOP with a probability test to establish whether samples collected in multiple years at the same localities could be pooled together to increase sample sizes. Significance levels $(p=0.05)$ were adjusted for simultaneous comparisons at multiple loci with the sequential Bonferroni correction (Rice, 1989).

A hierarchical analysis of molecular variance (AMOVA) based on $F_{\mathrm{ST}}$ (Weir and Cockerham, 1984; Michalakis and Excoffier, 1996) was performed in ARLEQUIN v.3.1 (Excoffier et al., 2005). Different hierarchical groupings of the samples were implemented to test multiple hypotheses for the temporal and spatial distribution of genetic variation.

We computed pairwise $F_{\mathrm{ST}}$ for all pairs of samples and significance levels $(p=0.05)$ were adjusted for simultaneous testing (Rice, 1989). Since $F_{\mathrm{ST}}$ values are dependent on the amount of within-population genetic variation rendering difficult comparisons across studies or markers (Hedrick, 2005), we also calculated a standardized $F_{\mathrm{ST}}$ as described by Meirmans (2006). This computation was performed using the software FSTAT v.2.9.3 (Goudet, 1995) and RECODEDATA v.0.1 (Meirmans, 2006). Isolation by geographic distance was tested within the Northwest Atlantic by plotting the genetic distance measures $F_{\mathrm{ST}} /\left(1-F_{\mathrm{ST}}\right)$ obtained between pairs of populations as a function of the geographic distances between those pairs (Rousset, 1997).

To test adult and larvae potential contribution to gene flow in the Northwest Atlantic, we considered two different geographic variables; one where geographic distances between populations were measured as the shortest marine distance, and one where measurements followed the directional flow of ocean currents. The major ocean surface currents in our area of study are shown in Fig. 1. Log-transformation was applied where appropriate (Rousset, 1997). An isolation-by-time scenario was not tested since sufficient short-spaced samples were not available (Hendry and Day, 2005).

For each relationship tested, we determined the Pearson simple correlation coefficient $(r)$, the significance of the relationships was established with Mantel tests for dependent data (Mantel, 1967) with R PACKAGE v.4.0 (Casgrain and Legendre, 2001), and ordinary least square (OLS) regressions were used to estimate the slopes and the intercepts of the linear fits.

The hypothetical subdivision of Greenland halibut of the Northwest Atlantic into distinct stocks was also tested using two Bayesian model-based clustering methods implemented in BAPS v.4.14 (Corander and Martinen, 2006) and STRUCTURE v.2.1 (Pritchard et al., 2000). Both methods assume the presence of $K$ populations, where $K$ may be unknown. BAPS v.4.14 uses stochastic optimization to infer the posterior mode of the genetic structure, while in STRUCTURE a Markov chain Monte Carlo procedure is used for estimation.

Genetic mixture analysis in BAPS was initially performed at the 'group level' clustering a priori defined population samples; the results of this analysis were then used to infer individual admixture (1000 iterations per individual, 500 reference individuals, 1000 iterations per reference individual, $p=0.05$ ) in a second set of analyses. For STRUCTURE we analyzed our data without supplying prior information on the origin of the samples, using the 'correlated frequencies' model, and allowing for admixture $\left(2 \times 10^{6}\right.$ dememorization iterations, $10^{6}$ chain iterations). The true number of populations was estimated computing $\Delta K$ over 10 runs for each $K$ following the method described by Evanno et al. (2005).

\section{Results}

\section{Sample size and microsatellite variation}

A total of 497 individual samples were included in the analysis (Table 1). Since allele frequencies differed significantly between years within the same site, samples could not be pooled across years. However, the samples collected in 1999 at sites 0A1, 0A2 and 0A3 could be pooled (0A-99), since no significant difference in allelic frequencies was observed between the sites.

Data collection was incomplete for loci Hhi57 and Hhi55 (39.7\% and $19.4 \%$ missing allelic data respectively, Table 2). The largest number of alleles (41) was found at Hhi57 for CSm-94, the smallest number (4) was recorded at locus Hhi55 for 0A2-93. The allelic richness $(A)$ was similar across population samples, with the exception of BE-94 samples, which showed higher genetic diversity.

Most locations showed significant heterozygote deficiency for at least one marker (Table 2). Accordingly, HWE was rejected at $17 \%$ of single-locus tests, twothirds of which involved either locus Hhi55 or Hhi57. Hhi55 contributed the highest $F_{\text {IS }}$ values and MICROCHECKER identified the presence of "null" alleles for this locus. When HWE tests were combined across loci, after exclusion of the two problematic markers, three samples (0A2-93, CSw-94 and BE-94) deviated from HWE, a result probably attributable to sub-structure in the samples (Wahlund effect). Only one pair of loci 
TABLE 2. Summary statistics for genetic variation in 14 samples of Greenland halibut. $N$, number of genotyped individuals per locus; $N_{\mathrm{A}}$, number of alleles per locus; $A$, allelic richness based on the smallest $N(N=7) ; F_{\mathrm{IS}}$, inbreeding coefficient calculated according to Weir and Cockerham (1984), bold value are significant $(p=0.005) ; H_{\mathrm{O}}$ and $H_{\mathrm{E}}$, observed and expected (Nei, 1987) heterozygosities.

\begin{tabular}{|c|c|c|c|c|c|c|c|c|c|c|c|c|c|c|c|}
\hline locus & & 0A2-93 & 0A-99 & 0A2-01 & 0B-93 & 0B-01 & CSw-93 & CSw-94 & CSm-94 & $1 \mathrm{~A}-01$ & 1C-99 & 1D-01 & SL1-94 & SL2-94 & BE-94 \\
\hline \multirow[t]{7}{*}{ Hhi3 } & $N$ & 25 & 40 & 20 & 39 & 18 & 48 & 48 & 50 & 20 & 47 & 20 & 43 & 25 & 49 \\
\hline & $N_{\mathrm{A}}$ & 13 & 14 & 12 & 11 & 8 & 15 & 12 & 16 & 12 & 11 & 12 & 15 & 10 & 21 \\
\hline & A & 7.006 & 5.859 & 6.086 & 5.541 & 5.326 & 6.058 & 5.98 & 6.185 & 7.194 & 5.128 & 6.263 & 6.546 & 5.899 & 9.115 \\
\hline & $F_{\text {IS }}$ & 0.233 & 0.155 & 0.056 & 0.210 & 0.091 & 0.078 & 0.200 & -0.053 & 0.135 & 0.005 & 0.086 & 0.154 & 0.011 & 0.140 \\
\hline & $H_{\mathrm{O}}$ & 0.640 & 0.675 & 0.750 & 0.615 & 0.722 & 0.750 & 0.625 & 0.860 & 0.750 & 0.766 & 0.700 & 0.698 & 0.800 & 0.796 \\
\hline & $H_{\mathrm{O}} S D$ & 0.096 & 0.074 & 0.097 & 0.078 & 0.106 & 0.062 & 0.070 & 0.049 & 0.097 & 0.062 & 0.102 & 0.070 & 0.080 & 0.058 \\
\hline & $H_{\mathrm{E}}$ & 0.830 & 0.797 & 0.794 & 0.777 & 0.792 & 0.813 & 0.780 & 0.817 & 0.864 & 0.770 & 0.764 & 0.823 & 0.809 & 0.924 \\
\hline \multirow[t]{7}{*}{ HhiA44 } & $N$ & 25 & 45 & 20 & 39 & 18 & 48 & 48 & 49 & 20 & 47 & 20 & 43 & 25 & 49 \\
\hline & $N_{\mathrm{A}}$ & 8 & 11 & 9 & 12 & 8 & 11 & 11 & 11 & 7 & 14 & 8 & 10 & 11 & 21 \\
\hline & A & 4.032 & 5.187 & 5.402 & 5.251 & 4.973 & 5.819 & 5.819 & 4.841 & 4.6 & 5.775 & 5.195 & 5.205 & 6.084 & 8.577 \\
\hline & $F_{\text {IS }}$ & 0.091 & 0.060 & 0.076 & -0.054 & 0.161 & 0.156 & 0.165 & 0.071 & -0.031 & 0.029 & 0.031 & 0.025 & 0.102 & 0.239 \\
\hline & $H_{\mathrm{o}}$ & 0.560 & 0.711 & 0.700 & 0.769 & 0.611 & 0.687 & 0.667 & 0.673 & 0.700 & 0.745 & 0.700 & 0.721 & 0.720 & 0.694 \\
\hline & $H_{\mathrm{o}} S D$ & 0.099 & 0.068 & 0.102 & 0.067 & 0.115 & 0.067 & 0.068 & 0.067 & 0.102 & 0.064 & 0.102 & 0.068 & 0.090 & 0.066 \\
\hline & $H_{\mathrm{E}}$ & 0.615 & 0.756 & 0.756 & 0.730 & 0.725 & 0.813 & 0.797 & 0.724 & 0.679 & 0.767 & 0.722 & 0.739 & 0.800 & 0.909 \\
\hline \multirow[t]{7}{*}{ Hhi55 } & $N$ & 7 & 29 & 20 & 19 & 18 & 47 & 27 & 50 & 20 & 47 & 20 & 22 & 25 & 49 \\
\hline & $N_{\mathrm{A}}$ & 4 & 7 & 5 & 5 & 6 & 9 & 6 & 7 & 5 & 10 & 6 & 6 & 10 & 13 \\
\hline & $A$ & 4 & 4.201 & 3.377 & 3.984 & 4.042 & 4.696 & 3.489 & 4.670 & 4.284 & 4.826 & 4.456 & 4.761 & 5.953 & 6.526 \\
\hline & $F_{\mathrm{IS}}$ & -0.034 & 0.367 & 0.238 & 0.383 & 0.005 & 0.353 & 0.293 & 0.462 & 0.187 & 0.487 & 0.385 & 0.416 & 0.450 & 0.160 \\
\hline & $H_{\mathrm{o}}$ & 0.714 & 0.414 & 0.350 & 0.421 & 0.667 & 0.468 & 0.444 & 0.400 & 0.600 & 0.383 & 0.450 & 0.454 & 0.440 & 0.694 \\
\hline & $H_{\mathrm{o}} S D$ & 0.171 & 0.091 & 0.107 & 0.113 & 0.111 & 0.073 & 0.096 & 0.069 & 0.110 & 0.071 & 0.111 & 0.106 & 0.099 & 0.066 \\
\hline & $H_{\mathrm{E}}$ & 0.692 & 0.649 & 0.456 & 0.676 & 0.670 & 0.721 & 0.625 & 0.740 & 0.735 & 0.743 & 0.724 & 0.771 & 0.793 & 0.825 \\
\hline \multirow[t]{7}{*}{ Hhi57 } & $N$ & 0 & 0 & 20 & 0 & 18 & 48 & 6 & 50 & 20 & 47 & 20 & 0 & 24 & 49 \\
\hline & $N_{\mathrm{A}}$ & - & - & 24 & - & 20 & 41 & 9 & 44 & 22 & 41 & 25 & - & 32 & 35 \\
\hline & A & - & - & - & - & - & - & - & - & - & - & - & - & - & - \\
\hline & $F_{\text {IS }}$ & - & - & 0.178 & - & 0.131 & 0.257 & 0.123 & -0.010 & 0.116 & 0.053 & -0.027 & - & 0.063 & 0.284 \\
\hline & $H_{\mathrm{O}}$ & - & - & 0.800 & - & 0.833 & 0.723 & 0.833 & 0.980 & 0.850 & 0.915 & 1.000 & - & 0.917 & 0.694 \\
\hline & $H_{\mathrm{o}} S D$ & - & - & 0.089 & - & 0.088 & 0.065 & 0.152 & 0.020 & 0.080 & 0.041 & 0.000 & - & 0.056 & 0.066 \\
\hline & $H_{\mathrm{E}}$ & - & - & 0.969 & - & 0.956 & 0.971 & 0.939 & 0.970 & 0.959 & 0.965 & 0.974 & - & 0.979 & 0.967 \\
\hline \multirow[t]{7}{*}{ Po091 } & $N$ & 25 & 45 & 20 & 39 & 18 & 48 & 48 & 50 & 20 & 47 & 20 & 43 & 25 & 49 \\
\hline & $N_{\mathrm{A}}$ & 11 & 19 & 12 & 17 & 12 & 18 & 20 & 17 & 13 & 18 & 13 & 19 & 13 & 25 \\
\hline & A & 6.559 & 7.824 & 7.492 & 7.524 & 7.71 & 6.278 & 8.562 & 6.382 & 6.816 & 6.472 & 7.337 & 7.426 & 6.999 & 9.234 \\
\hline & $F_{\text {IS }}$ & 0.387 & 0.051 & 0.191 & 0.140 & 0.107 & 0.057 & 0.194 & 0.064 & 0.033 & 0.005 & -0.123 & 0.164 & 0.055 & 0.141 \\
\hline & $H_{\mathrm{O}}$ & 0.480 & 0.822 & 0.700 & 0.718 & 0.778 & 0.729 & 0.729 & 0.740 & 0.800 & 0.787 & 0.950 & 0.721 & 0.800 & 0.796 \\
\hline & $H_{\mathrm{o}} S D$ & 0.100 & 0.057 & 0.102 & 0.072 & 0.099 & 0.064 & 0.064 & 0.062 & 0.089 & 0.060 & 0.049 & 0.068 & 0.080 & 0.058 \\
\hline & $H_{\mathrm{E}}$ & 0.777 & 0.866 & 0.861 & 0.833 & 0.868 & 0.773 & 0.903 & 0.790 & 0.827 & 0.791 & 0.849 & 0.861 & 0.846 & 0.925 \\
\hline
\end{tabular}

(Hhi44/Po91) showed evidence of LD in the Bering Sea sample. When tests were combined across all populations, all pairwise combinations of loci were in linkage equilibrium, excluding physical linkage. Although Knutsen et al. (2007) showed that null alleles at Hhi55 did not affect their analyses, we decided to exclude loci Hhi55 and Hhi57 from all analyses of population structure, keeping only three loci.
The 9-loci dataset included 96 samples from 0A2-01 $(n=41), 1 \mathrm{D}-01(n=20)$, and SL2-94 $(n=35)$. Ten samples from each site for a total of 30 were also part of the main set of 497 samples, the remaining 66 samples were additional samples not included in the main set. Merging of the data for these 66 additional samples with the main 3-loci dataset was not attempted since only two loci were shared. The 9-loci dataset was therefore analyzed sepa- 
POMILLA et al.: Population Structure in Greenland Halibut

TABLE 3. Hierarchical analysis of molecular variance (AMOVA) for 14 Greenland halibut spatial and temporal samples $(n=497)$.

\begin{tabular}{|c|c|c|c|}
\hline \multirow[b]{2}{*}{ Groups } & \multicolumn{3}{|c|}{$F$-statistics } \\
\hline & $\begin{array}{c}\% \text { total } \\
\text { variance }\end{array}$ & $\begin{array}{c}\text { Fixation } \\
\text { indices }\end{array}$ & $p$ \\
\hline \multicolumn{4}{|l|}{ All samples grouped by site } \\
\hline Among sites (spatial) & -0.72 & $\mathrm{CT}=-0.007$ & 0.68 \\
\hline Among years within sites (temporal) & 5.09 & $\mathrm{SC}=0.050$ & $\mathbf{0 . 0 0}$ \\
\hline Within samples & 95.64 & $\mathrm{ST}=0.044$ & $\mathbf{0 . 0 0}$ \\
\hline \multicolumn{4}{|l|}{ Subareas 014 grouped by site } \\
\hline Among sites (spatial) & -1.77 & $\mathrm{CT}=-0.018$ & 0.87 \\
\hline Among years within sites (temporal) & 5.24 & $\mathrm{SC}=0.051$ & $\mathbf{0 . 0 0}$ \\
\hline Within samples & 96.53 & $\mathrm{ST}=0.035$ & $\mathbf{0 . 0 0}$ \\
\hline \multicolumn{4}{|l|}{ Subareas 01 grouped by site } \\
\hline Among sites (spatial) & -1.63 & $\mathrm{CT}=-0.016$ & 0.82 \\
\hline Among years within sites (temporal) & 5.27 & $\mathrm{SC}=0.052$ & $\mathbf{0 . 0 0}$ \\
\hline Within samples & 96.36 & $\mathrm{ST}=0.036$ & $\mathbf{0 . 0 0}$ \\
\hline \multicolumn{4}{|l|}{ All samples grouped by year } \\
\hline Among years (temporal) & -0.65 & $\mathrm{CT}=-0.006$ & 0.82 \\
\hline Among sites within years (spatial) & 4.90 & $\mathrm{SC}=0.049$ & $\mathbf{0 . 0 0}$ \\
\hline Within samples & 95.75 & $\mathrm{ST}=0.042$ & $\mathbf{0 . 0 0}$ \\
\hline \multicolumn{4}{|l|}{ Subareas 014 grouped by year } \\
\hline Among years (temporal) & -0.66 & $\mathrm{CT}=-0.007$ & 0.76 \\
\hline Among sites within years (spatial) & 4.11 & $\mathrm{SC}=0.041$ & $\mathbf{0 . 0 0}$ \\
\hline Within samples & 96.55 & $\mathrm{ST}=0.034$ & $\mathbf{0 . 0 0}$ \\
\hline \multicolumn{4}{|l|}{ Subareas 01 grouped by year } \\
\hline Among years (temporal) & -1.11 & $\mathrm{CT}=-0.011$ & 0.86 \\
\hline Among sites within years (spatial) & 4.71 & $\mathrm{SC}=0.046$ & $\mathbf{0 . 0 0}$ \\
\hline Within samples & 96.40 & $\mathrm{ST}=0.036$ & $\mathbf{0 . 0 0}$ \\
\hline \multicolumn{4}{|l|}{ Subareas 014 grouped by Subarea } \\
\hline Among Subarea & -0.32 & $\mathrm{CT}=-0.032$ & 0.59 \\
\hline Among samples within Subarea & 3.76 & $\mathrm{SC}=0.037$ & $\mathbf{0 . 0 0}$ \\
\hline Within samples & 96.56 & $\mathrm{ST}=0.034$ & $\mathbf{0 . 0 0}$ \\
\hline \multicolumn{4}{|l|}{ Subareas 01 grouped by Subarea } \\
\hline Among Subarea & 0.29 & $\mathrm{CT}=0.003$ & 0.29 \\
\hline Among samples within Subarea & 3.66 & $\mathrm{SC}=0.037$ & $\mathbf{0 . 0 0}$ \\
\hline Within samples & 96.06 & $\mathrm{ST}=0.040$ & $\mathbf{0 . 0 0}$ \\
\hline \multicolumn{4}{|l|}{ Baffin Bay (North), Davis Strait (South) } \\
\hline Among Groups & -0.15 & $\mathrm{CT}=-0.001$ & 0.39 \\
\hline Among sites within Groups & 3.85 & $\mathrm{SC}=0.038$ & 0.00 \\
\hline Within sites & 96.30 & $\mathrm{ST}=0.037$ & 0.00 \\
\hline
\end{tabular}

Values shown in bold are significant $(P \leq 0.05)$ as estimated from 10000 random permutations.

rately. HWE was rejected at seven single-locus tests, all involving loci Hhil, Hhi53 or Hhi55. Knutsen et al. (2007) reported the presence of null alleles at these same markers.

\section{Genetic differentiation}

Spatial structure. In the first AMOVA (Table 3), temporal samples collected at the same site were grouped 
together and the molecular variance was partitioned into an among-sites component (spatial) and a within-site component (temporal). Most of the genetic variation was present within samples; the remaining variability was distributed among temporal samples within site, while the among-sites component exhibited a negligible value. These results did not change after the sequential exclusion of samples BE and SL. However, when we grouped spatial samples by year and the genetic variation was partitioned into an among-years component (temporal) and a within-year component (spatial), a significant component of the genetic variation was distributed among geographic samples within year, even after exclusion of BE, and SL. These combined results indicate that, although the temporal structure within a site is strong enough to obscure the among-sites component, there is significant spatial structure even within the Subareas 0-1 complex alone. The lack of significant variation among years suggests that while the distribution of variation varies across years at a small scale (within-site), it is nevertheless maintained over time at a larger scale (i.e. Northwest Atlantic).

In an attempt to reveal geographic patterns within the Northwest Atlantic we grouped sampling sites within the same NAFO Subarea, and we partitioned the genetic variation among NAFO Subareas, among samples within Subareas, and within samples (Table 3). No significant differences were detected among Subareas, regardless of the inclusion or exclusion of Subarea 4. Fish from CS (Subarea 0) may migrate offshore as far as Subarea 1 (Treble, MS 2002, MS 2003; Treble, unpublished data). Removal of this samples caused the genetic variation allocated between Subareas 0 and 1 to approach significance $(2.0 \%, p=0.08$, not shown in table). The 'within-Subarea' and 'within-sample' components of the genetic variation were significant for any combination of comparisons. Finally, the hypothesis of a Northern stock (Baffin Bay; 0A and 1A) and a Southern stock (Davis Strait; 0B, 1C, and 1D) was not supported by the AMOVA results, which showed that the Baffin Bay fish were not significantly different from fish sampled in the Davis Strait.

A locus-by-locus AMOVA confirmed that all three loci contributed similarly to the partition of the molecular variance observed in multilocus analyses.

The results for the $F_{\mathrm{ST}}$ pairwise comparisons are reported in Table 4. In general, several tests showed statistically significant differentiation. Within Subarea 0 we found variable degrees of spatial structure. Betweenyears $F_{\mathrm{ST}}$ tests revealed significant temporal differentiation within $0 \mathrm{~A}, 0 \mathrm{~B}$, and $\mathrm{CSw}$. The samples from Subarea 1 were homogeneous. The two samples collected in the Gulf of St Lawrence behaved differently in all pairwise comparisons, and SL1-94 was significantly different from Subarea 1 samples, while SL2-94 was not. As expected significant differentiation was obtained in all comparisons with the Bering Sea. Surprisingly, in a

TABLE 4. Pairwise genetic differentiation based on $F_{\mathrm{ST}}$ summary statistics for 14 Greenland halibut spatial and temporal samples $(n=497)$. The bottom half of the matrix shows the observed $F_{\mathrm{ST}}$, while the standardized $F_{\mathrm{ST}}$ is reported in the top half. Refer to text for details.

\begin{tabular}{llllllllllllllll}
\hline \hline & $0 A 2-93$ & $0 A-99$ & $0 A 2-01$ & $0 B-93$ & $0 B-01$ & CSw-93 & CSw-94 & CSm-94 & 1A-01 & 1C-99 & 1D-01 & SL1-94 & SL2-94 & BE-94 \\
\hline OA2-93 & & 0.135 & 0.307 & 0.227 & 0.291 & 0.339 & 0.274 & 0.300 & 0.220 & 0.297 & 0.386 & 0.229 & 0.311 & 0.522 \\
0A-99 & 0.030 & & 0.150 & 0.121 & 0.167 & 0.252 & 0.001 & 0.187 & 0.211 & 0.200 & 0.137 & 0.014 & 0.209 & 0.455 \\
OA2-01 & $\mathbf{0 . 0 7 3}$ & 0.027 & & 0.345 & -0.047 & 0.055 & 0.122 & 0.018 & 0.018 & -0.004 & 0.004 & 0.179 & -0.038 & 0.483 \\
OB-93 & $\mathbf{0 . 0 5 6}$ & $\mathbf{0 . 0 2 5}$ & $\mathbf{0 . 0 7 3}$ & & 0.384 & 0.490 & 0.102 & 0.426 & 0.396 & 0.423 & 0.428 & 0.044 & 0.415 & 0.437 \\
OB-01 & $\mathbf{0 . 0 7 1}$ & 0.031 & -0.006 & $\mathbf{0 . 0 8 3}$ & & 0.028 & 0.145 & -0.036 & -0.027 & -0.020 & -0.002 & 0.205 & -0.060 & 0.533 \\
CSw-93 & $\mathbf{0 . 0 7 8}$ & $\mathbf{0 . 0 4 6}$ & 0.013 & $\mathbf{0 . 1 0 3}$ & 0.008 & & 0.265 & 0.032 & 0.078 & 0.017 & 0.068 & 0.304 & 0.001 & 0.555 \\
CSw-94 & $\mathbf{0 . 0 6 1}$ & 0.000 & 0.025 & 0.021 & 0.030 & $\mathbf{0 . 0 5 1}$ & & 0.211 & 0.220 & 0.204 & 0.139 & -0.009 & 0.201 & 0.425 \\
CSm-94 & $\mathbf{0 . 0 7 4}$ & $\mathbf{0 . 0 3 5}$ & 0.005 & $\mathbf{0 . 0 9 5}$ & -0.007 & 0.007 & $\mathbf{0 . 0 4 3}$ & & 0.036 & 0.003 & 0.027 & 0.249 & -0.005 & 0.576 \\
1A-01 & $\mathbf{0 . 0 5 5}$ & $\mathbf{0 . 0 4 0}$ & 0.006 & $\mathbf{0 . 0 8 6}$ & -0.003 & 0.017 & $\mathbf{0 . 0 4 4}$ & 0.008 & & 0.006 & 0.117 & 0.218 & -0.021 & 0.562 \\
1C-99 & $\mathbf{0 . 0 7 2}$ & $\mathbf{0 . 0 3 8}$ & -0.000 & $\mathbf{0 . 0 9 4}$ & -0.003 & 0.004 & $\mathbf{0 . 0 4 1}$ & 0.001 & 0.002 & & 0.039 & 0.249 & -0.010 & 0.591 \\
1D-01 & $\mathbf{0 . 0 9 5}$ & 0.028 & 0.002 & $\mathbf{0 . 0 9 5}$ & 0.001 & 0.017 & 0.029 & 0.006 & 0.026 & 0.009 & & 0.200 & 0.018 & 0.584 \\
SL1-94 & $\mathbf{0 . 0 5 3}$ & 0.002 & 0.036 & 0.010 & $\mathbf{0 . 0 4 2}$ & $\mathbf{0 . 0 6 1}$ & 0.000 & $\mathbf{0 . 0 5 2}$ & $\mathbf{0 . 0 4 5}$ & $\mathbf{0 . 0 5 2}$ & $\mathbf{0 . 0 4 2}$ & & 0.238 & 0.470 \\
SL2-94 & $\mathbf{0 . 0 7 1}$ & $\mathbf{0 . 0 3 6}$ & -0.005 & $\mathbf{0 . 0 8 5}$ & -0.009 & 0.001 & $\mathbf{0 . 0 3 7}$ & -0.001 & -0.003 & -0.002 & 0.004 & $\mathbf{0 . 0 4 6}$ & \\
BE-94 & $\mathbf{0 . 0 8 7}$ & $\mathbf{0 . 0 5 7}$ & $\mathbf{0 . 0 6 6}$ & $\mathbf{0 . 0 6 6}$ & $\mathbf{0 . 0 7 5}$ & $\mathbf{0 . 0 7 8}$ & $\mathbf{0 . 0 5 5}$ & $\mathbf{0 . 0 8 7}$ & $\mathbf{0 . 0 8 0}$ & $\mathbf{0 . 0 9 0}$ & $\mathbf{0 . 0 8 6}$ & $\mathbf{0 . 0 6 5}$ & $\mathbf{0 . 0 7 0}$ & 0.540 \\
\hline
\end{tabular}

Values shown in bold are significant as estimated from 10000 random permutations following a sequential Bonferroni correction for multiple tests of critical value $p \leq 0.05$. Lines delimit Subareas, shaded cells indicate comparisons between samples collected from the same Subarea. Refer to Table 1 for population abbreviations. 
few instances $F_{\mathrm{ST}}$ values within the Northwest Atlantic were comparable to those reported for the comparisons with the Bering Sea. Standardized pairwise $F_{\mathrm{ST}}$ values are also reported in Table 4 as reference.

Consistent with these results we did not find significant differentiation among the three sites of the 9-loci dataset (0A2-01, 1D-01, SL2-94), regardless of the inclusion or exclusion of the three loci with null alleles (6 loci, 0A2-0/1D-01 $F_{\mathrm{ST}}=0.000,0 \mathrm{~A} 2-0 / \mathrm{SL} 2-94$ $\left.F_{\mathrm{ST}}=-0.005,1 \mathrm{D}-01 / \mathrm{SL} 2-94 F_{\mathrm{ST}}=0.001\right)$, and $F_{\mathrm{ST}}$ values were comparable to the ones obtained for the 3-loci dataset.

Plotting of $F_{\mathrm{ST}} /\left(1-F_{\mathrm{ST}}\right)$ as a function of geographic distance resulted in a negative correlation for both the matrix of shortest geographic log-distances $(r=-0.078)$, and the matrix of downcurrent distances $(r=-0.126)$ (Fig. 2), and the relationships were not statistically significant $(p>0.05)$. This result did not change when we corrected for temporal differences excluding pairwise comparisons between samples that had not been collected in the same year $(r=-0.182$ and $r=-0.296$ respectively; both: $p>0.05)$.

Number of populations. The Bayesian approach implemented in BAPS resolved the presence of two clusters of individuals in our sample from the Northwest Atlantic. Most of the fish (80\%) were assigned to one of the two identified clusters, while the remaining $20 \%$ had admixed genotypes (Fig. 3). The proportion of admixed fish was the same (19\%) in both Subarea 0 and 1. Significantly, most of the individuals from Subarea $1(97 \%$ of the non-admixed samples) clustered together in one partition (here referred as Cluster 2) whereas the non-admixed individuals of Subarea 0 were almost equally split between the two clusters. In particular, samples collected in 2001 in Divisions 0AB were represented in Cluster 2 , whereas most fish sampled in previous years at these locations grouped within Cluster 1 (Fig. 3).

Cumberland Sound samples were mostly allocated to Cluster 2, although the inshore location was more represented by Cluster 1 for 1994. We did not find a net North-South pattern, nevertheless, a higher proportion of samples from Davis Strait (66\% of the non-admixed samples; $70 \%$ if CS is included) were assigned to Cluster 2. The proportion of samples from Baffin Bay that was assigned to Cluster 1 (58\% of the non-admixed samples) reflects almost entirely $0 \mathrm{~A}$ samples, since the only site sampled in 1A clustered predominantly with Cluster 2, and therefore is not representative of the entire Baffin Bay. Consistent with $F_{\mathrm{ST}}$ results, 65\% of SL1-94 total samples were assigned to Cluster 1 , whereas $76 \%$ of SL2-94 total samples were assigned to Cluster 2.
Congruent results were obtained with STRUCTURE. The highest posterior probability $L(K)$ for the data was obtained when the samples were partitioned into two clusters, as also confirmed by the estimation of $\triangle K$. STRUCTURE estimates the proportion of ancestry from each of the $K$ clusters for each individual and the $90 \%$ probability intervals. The allocation of the samples to the clusters and the sample admixture proportions were similar to those obtained with BAPS (Fig. 4). However, the assignment of only $30 \%$ of the individuals (equally distributed between the two cluster) was supported by $90 \%$ probability intervals, suggesting a higher degree of
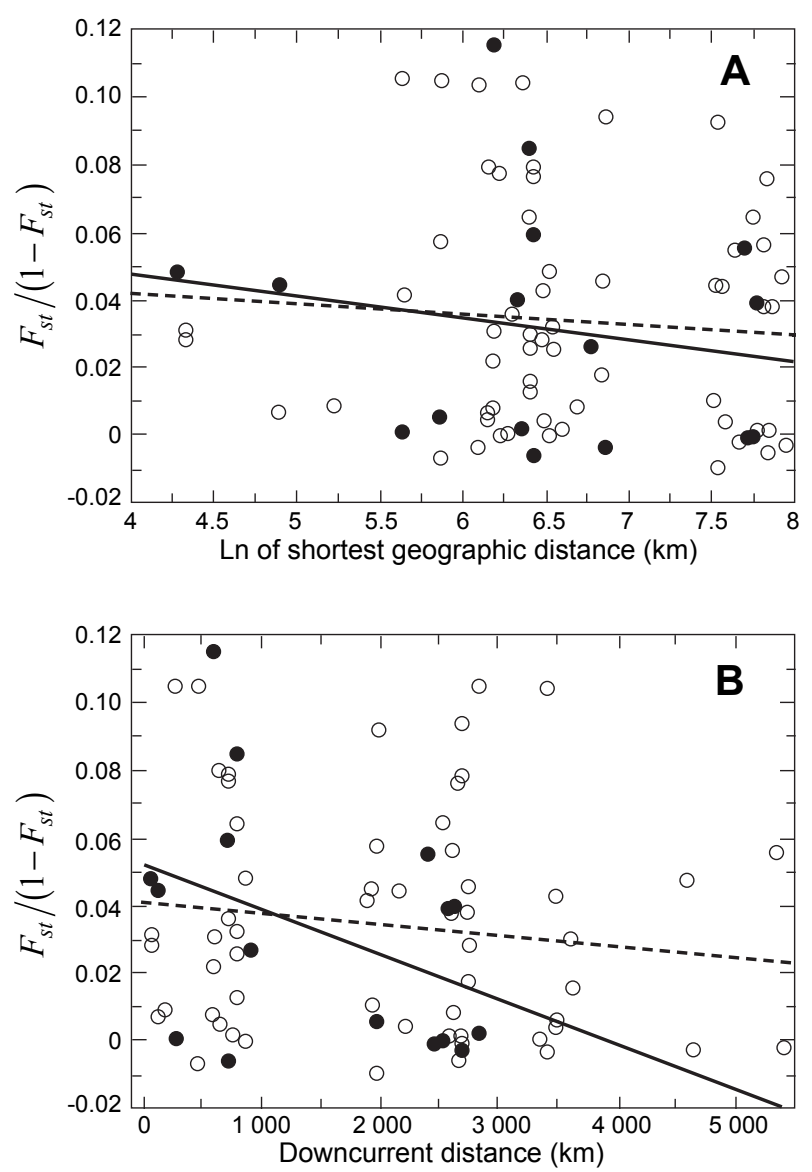

Fig. 2. Scatter plots and ordinary least square regression of genetic differentiation $\left(F_{\mathrm{ST}} / 1-F_{\mathrm{ST}}\right)$ against $(\mathbf{A})$ natural logarithm $(\mathrm{ln})$ of the shortest geographic distance between sites; (B) downcurrent distance between sites. Analyses included three NAFO Subareas $(0,1$, 4). Full circles refer to within-year pairwise comparisons. Dotted lines indicate the linear fit for all data points; continuous lines indicate the linear fit for full circles only. Mantel's correlation test for (A) all data points, $r=-0.078, p=0.51$; within-year pairwise comparisons, $r=-0.182, p=0.50$; and (B) all data points, $r=-0.126, p=0.28$; within-year pairwise comparisons, $r=-0.396, p=0.13$. 


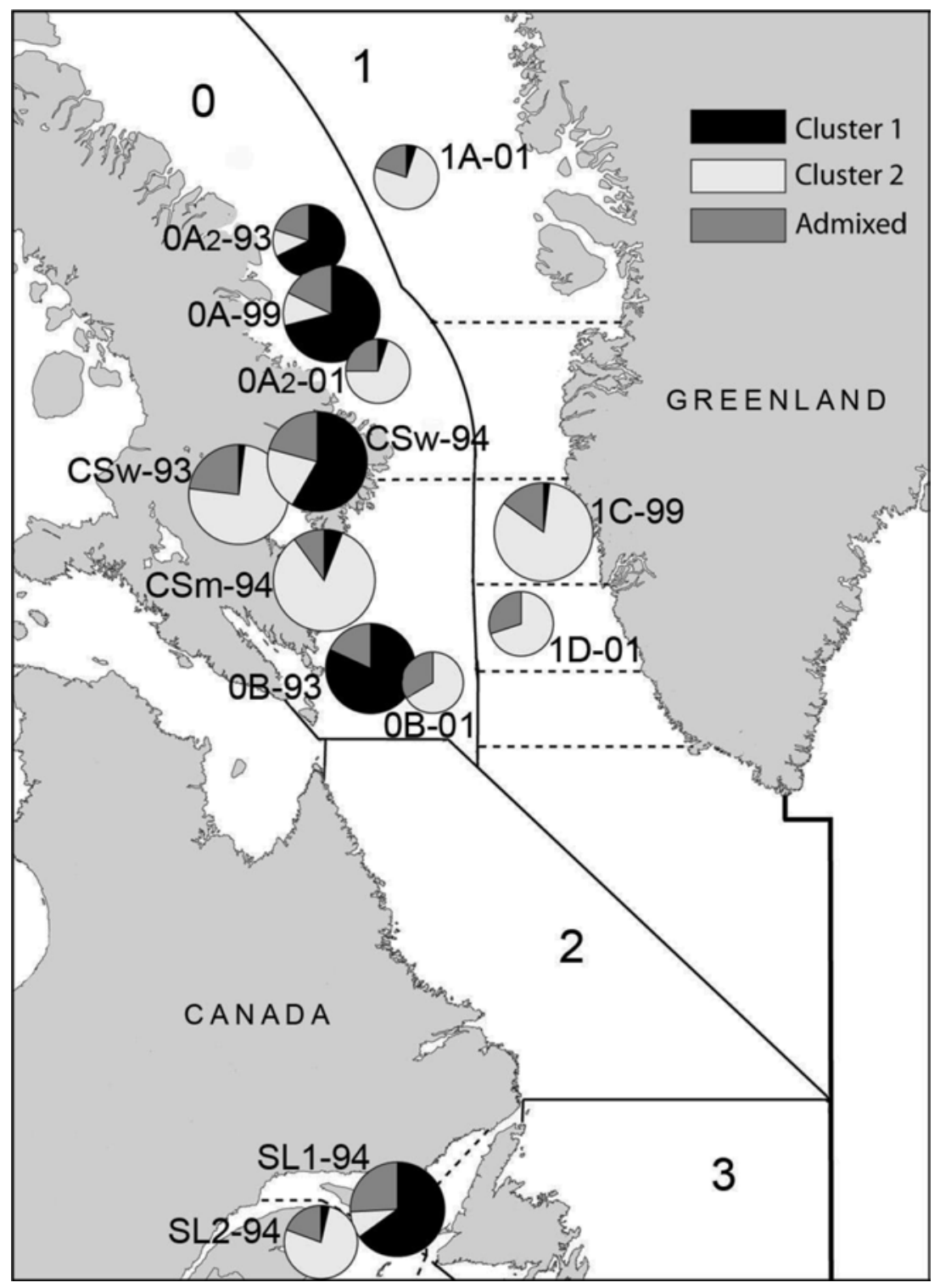

Fig. 3. Allocation of fish from three NAFO Subareas $(0,1,4)$ to each of two clusters inferred from BAPS mixture clustering and individual admixture analyses. The proportion of individuals with significantly $(p \leq 0.05)$ admixed ancestry is also indicated. The size of the pie charts is proportional to the sample size.

admixture than the one indicated by BAPS. The exclusion of the Gulf of St Lawrence did not change the estimate of the true $K$ as $K=2$, or the assignment distributions (data not shown). The inclusion of the Bering Sea sample instead raised the number of true clusters to $K=3$ (data not shown). In this latter analysis the composition of the first two clusters was approximately maintained as in the analysis for Subareas 0 and 1 only, whereas the third cluster contained the majority of the samples from the Bering Sea. Some resolution was, however, lost and a larger proportion of samples showed a high degree of admixture or was assigned to the third cluster. The cluster most affected was Cluster 1, suggesting lower divergence between this cluster and the Bering Sea.

Variance in reproductive success may cause temporal differentiation between cohorts (Hedgecock, 1994), leading to the detection of different clusters. Although we were not able to partition our samples into cohort due to the already small sample sizes and incomplete length information, an ANOVA showed that length, a proxy for age, could explain the assignment of fish into one 


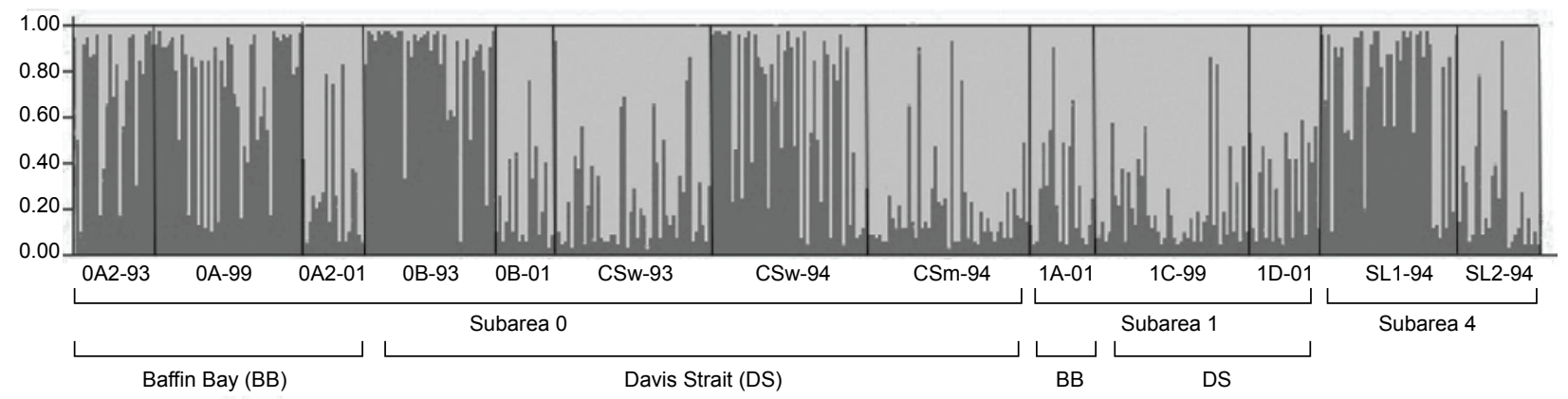

Fig. 4. Probabilities for 448 fish from three NAFO Subareas $(0,1,4)$ to be assigned to any of $K=2$ clusters by STRUCTURE. Each individual is represented by a vertical line, which is partitioned into two coloured segments representing the estimated membership fraction of each sample in two clusters. Dark gray corresponds to Cluster 1 of Fig. 4, and light gray corresponds to Cluster 2. Black lines separate fish collected at different time or location (refer to Table 1 for sample abbreviations). Northern or Southern origin of the samples within the Northwest Atlantic is indicated by the Baffin Bay and Davis Strait labels.

of the two clusters $(F=6.60, p=0.01$, larval fish were excluded).

Clustering analyses following both of the above approaches failed to detect any partitions for the samples in the 9-loci dataset, regardless of the inclusion or exclusion of the three loci with null alleles. This result was not surprising, because of the 30 samples shared between this dataset and the main dataset, in the 3-loci clustering analyses, 25 were assigned to Cluster 2 and five resulted admixed.

\section{Discussion}

Twenty or more years of studies (Smidt, 1969; Templeman, 1970; Fairbairn, 1981; Khan et al., 1992; Riget et al., 1992; Arthur and Albert, 1993; Boje et al., 1997; Vis et al., 1997; Boje, 2002) of the biological stock structure of Greenland halibut have shown that this species forms a single stock in the Northwest Atlantic with the exceptions of the area of the Gulf of St. Lawrence (Subarea 4), which seems to be distinct to a certain degree, and of the West Greenland Fjords, although not all the evidence collected has supported the differentiation of the latter. The approaches used previous to our study have failed to find any differentiation within the Baffin Island-West Greenland complex spanning NAFO Subareas 0 and 1 .

The results here presented are only based on three microsatellite markers, and as such they should only be considered as preliminary. Nevertheless we identified several potentially interesting patterns that warrant verification with the addition of more markers and samples where possible (Ruzzante, 1998; Kalinowski, 2005). Preliminary data for nine microsatellite markers for three sites agree so far with the results obtained with three markers.

Our data suggest that the Greenland halibut of the Northwest Atlantic from Subarea 0, 1 and 4 comprise two distinct genetic clusters. Analyses of molecular variance, $F$-statistics values for pairwise comparisons, and two independent Bayesian clustering analyses congruently support this conclusion. Although additional considerations, besides genetic data, may be called for to establish whether the two clusters identified define distinct stocks (Ihssen et al., 1981), for simplicity of the discussion from now on we will address them as stocks.

Interestingly, the two stocks are represented both within the Baffin Island-West Greenland complex and in the Gulf of St. Lawrence, suggesting that there may not be marked genetic distinction between fish from these two areas of the Northwest Atlantic. Within the Baffin Island-West Greenland complex, Stock 1 is present almost exclusively in Subarea 0, whereas Stock 2 is equally represented in Subareas 0 and 1. The hypothesis of a northern and a southern stock is not supported by any of our results. Rather, the relative distribution of the two stocks appears more representative of an East-West partial differentiation in the northern part of Baffin Bay. Stochasticity may have also played a role in the resulting distribution of the two stocks, since Subarea 0 was more heavily sampled.

It is not surprising that our results contrast with the conclusions of previous studies. Microsatellites have been more powerful in detecting differentiation in high gene flow species such as Atlantic cod (Gadus morhua, Ruzzante et al., 1998), hake (Merluccius merluccius, Lundy et al., 2000) and squid (Loligo forbesi, Shaw et 
al., 1999), and, as shown for turbot (Scophthalmus maximus, Nielsen et al., 2004), the final result often depends on the areas sampled.

Most spawning of Greenland halibut in the Northwest Atlantic takes place over an extended area from Davis Strait to Newfoundland with a peak during winterspring (Jensen, 1935; Smidt, 1969; Templeman, 1973). Larvae are transported from spawning grounds in Davis Strait to and along the west coast of Greenland to northern Davis Strait and then southward toward the banks off Baffin Island (Bowering and Chumakov, 1989). Our efforts to correlate genetic differentiation with geographic distance showed no clear pattern of gene flow mediated by either larval dispersal or adult migration. It is likely that the observed geographic distribution of genetic variation is generated by a complex combination of the two. Our larval samples (1C) grouped almost entirely with Stock 2, with the exception of some admixed fish, suggesting the existence of another spawning area (or season) for Stock 1.

The poor knowledge on the spawning affiliation of the samples adds complexity, since presumed populations may indeed constitute mixtures of different stocks sampled on common grounds during feeding migrations. For instance, about ten years of studies were needed to confirm the genetic differentiation between the eastern and western Atlantic bluefin tuna (Thunnus thynnus) stocks due to the mixing of adults on feeding grounds (Carlsson et al., 2007). Many flatfishes undergo seasonal migrations related to feeding and return to specific areas to spawn. Natal homing is certainly a key factor in the geographic structuring of these populations, yet very little is known about its mechanisms for this group (Bailey, 1997; Hoarau et al., 2002). True population structure of Greenland halibut may be difficult to identify with our current samples, as they were collected during summer (with the exception of CSw) when feeding behaviour may have caused mixing of fish from the two identified stocks.

Observations from fishermen in the winter fishery well within Cumberland Sound suggest some spawning occurs within this 'inshore' area of the Sound. Despite this local spawning, this 'inshore' population may heavily depend on recruitment from the Davis Strait, similarly to the fish in the West Greenland fjords (Riget and Boje, 1989). Tagging has indeed shown that fish from the mouth of Cumberland Sound migrate inshore within Cumberland Sound as well as to deeper offshore waters in the Davis Strait (Division 0B) (Treble, MS 2003). Our analyses show that the 'inshore' component of Cumberland Sound includes fish from Stock 1 as well as fish from Stock 2 while at the mouth of the Sound Stock 2 is predominant.

Within the Gulf of St. Lawrence, the analysis of samples scattered through the northern part of the Gulf, up into the estuary of the St. Lawrence River, (mainly Division 4S) indicates a strong prevalence of fish from Stock 1. However, fish collected with a single tow off the Gaspé Peninsula (Division 4T) belonged almost entirely to Stock 2. Stock 1 may represent here the 'resident inshore' stock, known to spawn in the Laurentian Channel off Southwestern Newfoundland, while the fish sampled off the Gaspé Peninsula could be a component of the 'offshore' stock that may utilize habitat in the Gulf for feeding. These fish might also have been recruited into the Gulf of St. Lawrence from Davis Strait, as previously suggested by Bowering (1982). Spawning in the Gulf takes place in winter in the Laurentian Channel between Anticosti Island and Cabot Strait (Bowering, 1980); however, a very few number of spent fish have also been observed during summer surveys (B. Bernier, personal communication, 2008). Two different spawning seasons could be reflective of two stocks (Hendry and Day, 2005); for instance, Atlantic cod over-wintering in the Gulf of St Lawrence consist of a mixture of several spawning populations (Ruzzante et al., 2000).

Our data showed across-years variation in genetic composition at the small scale (within-site), but a lack of significant variation among years when pooling all samples from the Baffin Island-West Greenland complex. Temporal variation in our samples may be due to sampling bias introduced by non-homogenous distributions of the stocks. During spawning different stocks may form distinct spatial assemblages within the same site, rather than intermingling, perhaps due to differences in spawning timing (Ruzzante et al., 2000). However, the heterogeneity of the life-stages sampled adds another not-negligible temporal dimension in the data.

In summary, the evidence here presented collectively suggest that Greenland halibut of the Northwest Atlantic between Baffin Island and West Greenland are not comprised of a single panmictic assemblage, but rather are composed of two genetically distinguishable stocks. However, the geographic intermingling, and possibly admixing, of the two stocks, at least in Subarea 0, reinforces that, until more information is available, continuing to manage Subareas 0 and 1 as a single unit is reasonable. Because the current dataset includes many different life-stages and cohorts, the caveat holds that variance in reproductive success may have caused temporal differentiation between cohorts (Hedgecock, 1994), leading to the detection of two different clusters. We interpreted the 
observed heterozygote deficiencies with substructure in our samples due to the presence at most locations of the two stocks. It has been shown that when a larval cod aggregation showing heterozygote deficiency was divided into cohorts using length as a proxy for age, no departure from Hardy-Weinberg expectation was observed in each cohort (Ruzzante et al., 1996). We found an overall relationship between the length of the fish and the cluster identity; yet, this could be attributed to a non-homogeneous sampling strategy (e.g. different strata sampled in different occasions).

These preliminary findings warrant further investigation with intensive sampling conducted in sequential years at multiple sites across Baffin Bay and the Davis Strait, as well as additional markers. To solve issues associated with seasonal movements and different lifestages, spawning adults should be ideally sampled, however, this is almost impossible for Greenland halibut in the Northwest Atlantic, where the fishery shuts down for five months (November-March) due to ice conditions. Although some trawl activity persists during DecemberJanuary, this gear is not indicated for large spawning fish that can easily swim away from it. The samples most readily available to us would be the juvenile-pre-adults caught prior to spawning.

In addition, now that the genetic tools have been identified it would be relevant to investigate further the relationship between the Baffin Island-West Greenland complex and the Labrador-eastern Newfoundland and Gulf of St. Lawrence management units. This information is very much needed for careful management of the Greenland halibut fishery in the NAFO Regulatory area.

\section{Acknowledgements}

Funding for this research was provided by Fisheries and Oceans Canada and the Government of the Northwest Territories EDA Sub-Committee for fisheries. Doug Chiperzak assisted with the development of this research program and conducted sampling in Cumberland Sound. We thank the following individuals for their help in acquiring samples from the other areas examined in our study; Beverley Hathaway, Johnny McPherson, Terry Sample, Joe Firth, Dennis Rice, Alain Frechet, Hugue Benoit, Claus Simonson and Ole Jørgensen. Ole Thomas Albert and Halvor Knutsen provided additional genetic information for a subset of our samples. Sergios Orestis Kolokotronis provided valuable comments on the manuscript.

\section{References}

ACIA. MS 2005. Arctic Climate Impact Assessment. Cambridge University Press, $1042 \mathrm{p}$.

ARTHUR, J. R., and E. ALBERT. 1993. Use of parasites for separating stocks of Greenland halibut (Rheinardtius hippoglossoides) in the Canadian Northwest Atlantic. Can. J. Fish. Aquat. Sci., 50: 2175-2181. doi:10.1139/f93-243

BAILEY, K. M. 1997. Structural dynamics and ecology of flatfish populations. J. Sea Res., 37: 269-280. doi:10.1016/ S1385-1101(97)00018-X

BELKHIR, K., P. BORSA, L. CHIKHI, N. RAUFASTE, and F. BONHOMME. 2004. GENETIX 4.05, software for Windows platform for population genetics. Laboratoire Génome, Populations, Interactions, CNRS UMR 5171, Université de Montpellier II, Montpellier, France.

BOJE, J. 2002. Intermingling and seasonal migrations of Greenland halibut (Reinhardtius hippoglossoides) populations determined from tagging studies. Fish. Bull., 100: 414-422.

BOJE, J., F. RIGET, and M. KØIE. 1997. Helminth parasites as biological tags in population studies of Greenland halibut ((Reinhardtius hippoglossoides) (Walbaum)), in the north-west Atlantic. ICES J. Mar. Sci., 54: 886-895. doi:10.1006/jmsc.1997.0214

BOWERING, W. R. 1980. Fecundity of Greenland halibut, Reinhardtius hippoglossoides (Walbaum), from southern Labrador and southeastern Gulf of St. Lawrence. J. Northw. Atl. Fish. Sci., 1: 39-43.

1982. Population dynamics of Greenland halibut in the Gulf of St. Lawrence. J. Northw. Atl. Fish. Sci., 3: 141-147.

1984. Migrations of Greenland halibut, Reinhardtius hippoglossoides, in the Northwest Atlantic from tagging in the Labrador-Newfoundland region. J. Northw. Atl. Fish. Sci., 5: 85-91.

BOWERING, W. R., and W. B. BRODIE. 1995. Greenland halibut (Rheinardtius hippoglossoides): a review of the dynamics of its distribution and fisheries off eastern Canada and Greenland. In: Deep-water fisheries of the North Atlantic slope. A. G. Hopper (ed.). Kluwer Academic Publishers, Netherlands, p. 113-160.

BOWERING, W. R., and A. K. CHUMAKOV. 1989. Distribution and relative abundance of Greenland halibut (Reinhardtius hippoglossoides (Walbaum)) in the Canadian Northwest Atlantic from Davis Strait to the northern Grand Bank. Fish. Res., 7: 301-328. doi:10.1016/0165-7 836(89)90064-7

CARLSSON, J., J. R. MCDOWELL, J. E. L. CARLSSON, and J. E. GRAVES. 2007. Genetic identity of YOY bluefin tuna from the eastern and western Atlantic spawning areas. J. Hered., 98: 23-28. doi:10.1093/jhered/es1046

CASGRAIN, P., and P. LEGENDRE. 2001. The R Package for multivariate and spatial analysis, version $4.0 \mathrm{~d} 6$. Département de Sciences Biologiques, Université de Montréal.

CORANDER, J., and P. MARTTINEN. 2006. Bayesian identification of admixture events using multilocus molecular 
markers. Mol. Ecol., 15: 2833-2843.

COUGHLAN, J., M. STEFANSSON, P. GALVIN, E. DILLANE, R. FITZGERALD, and T. F. CROSS. 2000. Isolation and characterization of 11 microsatellite loci in Atlantic halibut (Hippoglossus hippoglossus L.). Mol. Ecol., 9: 817-829. doi:10.1046/j.1365-294x.2000.009153.x

DEVINE, J. A., K. D. BAKER, and R. L. HAEDRICH. 2006. Deep-sea fishes qualify as endangered. Nature, 439: 29. doi: $10.1038 / 439029$ a

EVANNO, G., S. REGNAUT, and J. GOUDET. 2005. Detecting the number of clusters of individuals using the software STRUCTURE: a simulation study. Mol. Ecol., 14: 2611-2620. doi:10.1111/j.1365-294X.2005.02553.x

EXCOFFIER, L., L. G. LAVAL, and S. SCHNEIDER. 2005. Arlequin (version 3.0): An integrated software package for population genetics data analysis. Evolution. Bioinf. Online, 1: 47-50. http://www.la-press. com/redirect_file.php?fileId=231\&filename $=$ EBO-1Excoffier(Sc)\&fileType $=$ pdf

FAIRBAIRN, D. J. 1981. Biochemical genetic analysis of population differentiation in Greenland halibut (Reinhardtius hippoglossoides) from the Northwest Atlantic, Gulf of St. Lawrence, and Bering Sea. Can. J. Fish. Aquat. Sci., 38: 669-677. doi:10.1139/f81-090

FRCC. MS 1994. 1995 conservation requirements for Atlantic groundfish: report to the Minister of Fisheries and Oceans. Fisheries Resource Conservation Council, Minister of Supply and Services, $138 \mathrm{p}$.

GOUDET, J. 1995. FSTAT (Version 1.2): a computer program to calculate $F$-statistics. J. Hered., 86: 485-486.

GUO, S., and E. THOMPSON. 1992. Performing the exact test of Hardy Weinberg proportion for multiple alleles. Biometrics, 48: 361-372. doi:10.2307/2532296

HEDGECOCK, D. 1994. Temporal and spatial genetic structure of marine animal populations in the California Current. CalCOFOI Rep., 35: 73-81. http://www.calcofi. org/newhome/publications/CalCOFI_Reports/v35/pdfs/ Vol_35_Hedgecock.pdf

HEDRICK, P. W. 2005. A standardized genetic differentiation measure. Evolution, 59: 1633-1638.

HENDRY, A. P., and T. DAY. 2005. Population structure attributable to reproductive time: isolation by time and adaptation by time. Mol. Ecol., 14: 901-916. doi:10.1111/j.1365294X.2005.02480.x

HOARAU, G., A. D. RIJNSDORP, H. W. VAN DER VEER, W. T. STAM, and J. L. OLSEN. 2002. Population structure of plaice (Pleuronectes platessa L.) in northern Europe: microsatellites revealed large-scale spatial and temporal homogeneity. Mol. Ecol., 11: 1165-1176. doi:10.1046/ j.1365-294X.2002.01515.x

IHSSEN, P. E., H. E. BOOKE, J. M. CASSELMAN, J. M. MCGLADE, N. R. PAYNE, and F. M. UTTER. 1981. Stock identification: materials and methods. Can. J. Fish. Aquat. Sci., 38: 1838-1855. doi:10.1139/f81-230

JENSEN, A. S. 1935. The Greenland halibut (Reinhardtius hippoglossoides) its development and migration. K. Dan. Vidensk. Selsk. Skr., 9: 1-32.

JUNQUERA, S., and J. ZAMARRO. 1994. Sexual maturity and spawning of Greenland halibut (Reinhardtius hippoglossoides) from Flemish Pass Area. NAFO Sci. Coun. Studies, 20: 47-52.

KALINOWSKI, S. T. 2005. Do polymorphic loci require large sample size to estimate genetic distances? Heredity, 94: 33-36. doi:10.1038/sj.hdy.6800548

KHAN, R. A., A. DAWE, W. R. BOWERING, and R. K. MISRA. 1992. Blood protozoa as an aid for separating stocks of Greenland halibut, Reinhardtius hippoglossoides, in the Northwestern Atlantic. Can. J. Fish. Aquat. Sci., 39: 1317-1322.

KNUTSEN, H., P. E. JORDE, O. T. ALBERT, R. HOELZEL, and N. C. STENSETH. 2007. Population genetic structure influenced by oceanic current systems in the North Atlantic Greenland halibut. Can. J. Fish. Aquat. Sci., 64: 857-866. doi:10.1139/F07-070

KNUTSEN, H., P. E. JORDE, C. ANDRÉ, and N. C. STENSETH. 2003. Fine-scale geographical population structuring in a highly mobile marine species: the Atlantic cod. Mol. Ecol., 12: 385-394. doi:10.1046/j.1365294X.2003.01750.x

LUNDY, C. J., C. RICO, and G. M. HEWITT. 2000. Temporal and spatial genetic variation in spawning grounds of European hake (Merluccius merluccius) in the Bay of Biscay. Mol. Ecol., 9: 2067-2079. doi:10.1046/j.1365294X.2000.01120.x

MANTEL, N. 1967. The detection of disease clustering and a generalized regression approach. Cancer Res., 27: 209-220.

MCGOVAN, C., and M. E. REITH. 1999. Polymorphic microsatellite markers for Atlantic halibut, Hippoglossus hippoglossus. Mol. Ecol., 8: 1753-1768. doi:10.1046/j.1365294x.1999.00723.x

MEIRMANS, P. G. 2006. Using the AMOVA framework to estimate a standardized genetic differentiation measure. Evolution, 60: 2399-2402.

MICHALAKIS, Y., and L. EXCOFFIER. 1996. A generic estimation of population subdivision using distance between alleles with special reference for microsatellite loci. $\mathrm{Ge}$ netics, 142: 1061-1064.

NAFO. MS 1994. Report of Scientific Council, 8-22 June 1994 meeting. NAFO SCS Doc., No. 19, Serial No. N2435, $88 \mathrm{p}$.

NEI, M. 1987. Molecular Evolutionary Genetics. Columbia University Press, New York. 526 p.

NIELSEN, E. E., M. M. HANSEN, and D. E. RUZZANTE. 2003. Evidence of a hybrid-zone in Atlantic cod (Gadus morhua) in the Baltic and the Danish Belt Sea revealed by individual admixture analysis. Mol. Ecol., 12: 1497-1508. doi:10.1046/j.1365-294X.2003.01819.x

NIELSEN, E. E., P. H. NIELSEN, D. MELDRUP, and M. M. HANSEN. 2004. Genetic population structure of turbot (Scophthalmus maximus L.) supports the presence of multiple hybrid zones for marine fishes in the transition zone between the Baltic Sea and the North Sea. Mol. Ecol., 13: 585-595. doi:10.1046/j.1365-294X.2004.02097.x

PRITCHARD, J. K., M. STEPHENS, and P. DONNELLY. 2000. Inference of Population Structure Using Multilocus Genotype Data. Genetics, 155: 945-959. 
RAYMOND, M., and F. ROUSSET. 1995. GENEPOP (Version $1.2)$ : population genetic software for exact tests and ecumenicism. J. Hered., 86: 248-249.

RICE, W. R. 1989. Analyzing table of statistical tests. Evolution, 43: 223-225. doi:10.2307/2409177

RIGET, F., and J. BOJE. 1989. Fishery and some biological aspects of Greenland halibut (Reinhardtius hippoglossoides) in West Greenland waters. NAFO Sci. Coun. Studies, 13: 41-52.

RIGET, F., J. BOJE, and V. SIMONSEN. 1992. Analysis of meristic and genetic differentiation in Greenland halibut (Reinhardtius hippoglossoides) in the Northwest Atlantic. J. Northw. Atl. Fish. Sci., 12: 7-14.

ROESSIG, J. M., C. M. WOODLEY, J. J. CECH, and L. J. HANSEN. 2004. Effects of global climate change on marine and estuarine fishes and fisheries. Rev. Fish Biol. Fish., 14: 251-275. doi:10.1007/s11160-004-6749-0

ROUSSET, F. 1997. Genetic differentiation and estimation of gene flow from $F$-statistics under isolation by distance. Genetics, 145: 1219-1228.

RUZZANTE, D. E. 1998. A comparison of several measures of genetic distance and population structure with microsatellite data: bias and sampling variance. Can. J. Fish. Aquat. Sci., 55: 1-14. doi:10.1139/cjfas-55-1-1

RUZZANTE, D. E., C. T. TAGGART, and D. COOK. 1996. Spatial and temporal variation in the genetic composition of a larval cod (Gadus morhua) aggregation: Cohort contribution and genetic stability. Can. J. Fish. Aquat. Sci., 53: 2695-2705. doi:10.1139/cjfas-53-12-2695

1998. A nuclear DNA basis for shelf- and bank-scale population structure in northwest Atlantic cod (Gadus morhua): Labrador and Georges Bank. Mol. Ecol., 7: 1663-1680.

RUZZANTE, D. E., C. T. TAGGART, S. LANG, and D. COOK. 2000. Mixed-stock analysis of Atlantic cod near the Gulf of St. Lawrence based on microsatellite DNA. Ecol. Appl., 10: 1090-1109. doi:10.1890/10510761(2000)010[1090:MSAOAC]2.0.CO;2

SEKINO, M., and M. HARA. 2000. Isolation and characterization of microsatellite DNA loci in Japanese flounder Paralichthys olivaceus (Pleuronectiformes, Pleuronectoidei, Paralichthydae). Mol. Ecol., 9: 2200-2202. doi:10.1046/ j.1365-294X.2000.105325.x

SHAW, P. W., A. I. ARKHIPKIN, and H. AL-KHAIRULLA. 2004. Genetic structuring of Patagonian toothfish populations in the Southwest Atlantic Ocean: the effect of the Antarctic Polar Front and deep-water troughs as bar- riers to genetic exchange. Mol. Ecol., 13: 3293-3303. doi:10.1111/j.1365-294X.2004.02327.x

SHAW, P. W., G. J. PIERCE, and P. R. BOYLE. 1999. Subtle population structuring within a highly vagile marine invertebrate, the veined squid Loligo forbesi, demonstrated with microsatellite markers. Mol. Ecol., 8: 407-417. doi:10.1046/j.1365-294X.1999.00588.x

SMIDT, E. L. B. 1969. The Greenland halibut, Reinhardtius hippoglossoides (Walb.), biology and exploitation in Greenland waters. Medd. Dan. Fisk. Havunders., 6: 79-148.

TAYLOR, E. B., and M. E. HELLBERG. 2003. Genetic evidence for local retention of pelagic larvae in the Caribbean reef fish. Science, 299: 107-109. doi:10.1126/science. 1079365

TEMPLEMAN, W. 1970. Vertebral and other meristic characteristics of Greenland halibut, Reinhardtius hippoglossoides, from the Northwest Atlantic. J. Fish. Res. Board Can., 27: 1549-1562.

1973. Distribution and abundance of the Greenland halibut, Reinhardtius hippoglossoides (Walbaum), in the Northwest Atlantic. ICNAF Res. Bull., 10: 83-98.

TREBLE, M. A. MS 2002. Analysis of data from the 2001 Trawl Survey in NAFO Subarea 0. NAFO SCR. Doc., No. 47 Serial No. N4659, 28 p.

MS 2003. Results of a Greenland halibut (Reinhardtius hippoglossoides) tagging project in Cumberland Sound, NAFO Division 0B, 1997-2000. NAFO SCR. Doc., No. 41 Serial No. N4859, 7 p.

VAN OOSTERHOUT, C., W. F. HUTCHINSON, D. P. M. WILLS, and P. SHIPLEY. 2004. MICRO-CHECKER: software for identifying and correcting genotyping errors in microsatellite data. Mol. Ecol. Notes, 4: 535-538. doi:10.1111/j.1471-8286.2004.00684.x

VIS, M. L., S. M. CARR, W. R. BOWERING, and S. DAVIDSON. 1997. Greenland halibut (Reinhardtius hippoglossoides) in the North Atlantic are genetically homogeneous. Can. J. Fish. Aquat. Sci., 54: 1813-1821. doi:10.1139/cjfas-54-8-1813

WARD, R. D. 2000. Genetics in fisheries management. Hydrobiologia, 420: 191-201. doi:10.1023/A:1003928327503

WEIR, B. S., and C. C. COCKERHAM. 1984. Estimating $F$-statistics for the analysis of population structure. Evolution, 38: 1358-1370. doi:10.2307/2408641

WIRTH, T., and L. BERNATCHEZ. 2001. Genetic evidence against panmixia in the European eel. Nature, 409: 1037-1040. doi:10.1038/35059079 